\title{
Increase of Graduates by the Thesis Development at Public Universities in Peru through Collaborative Motivation
}

\author{
Hugo Vega ${ }^{a}$, Santiago Moquillaza ${ }^{b}$, Ciro Rodríguez ${ }^{c}$, Frank Escobedo ${ }^{d}$, Oscar Benito ${ }^{\mathrm{e}}$, 6Javier Gamboa Gam $^{\mathrm{f}}$ \\ a, b, c, d, e, fUniversidad Nacional Major de San Marcos, UNMSM, Lima, Peru \\ ${ }^{\mathrm{d}}$ Universidad Nacional Tecnologica de Lima Sur, UNTELS, Lima, Peru \\ ahvegah@unmsm.edu.pe, ${ }^{\mathrm{b}}$ smoquillazah@unmsm.edu.pe, ${ }^{\mathrm{c}}$ crodriguezro@unmsm.edu.pe, ${ }^{\mathrm{d}}$ fescobedo@untels.edu.pe, \\ ebenitop@unmsm.edu.pe, figamboa@unmsm.edu.pe
}

Article History: Received: 10 November 2020; Revised 12 January 2021 Accepted: 27 January 2021; Published online: 5 April 2021

\begin{abstract}
In Peru, there is a deficit of university students who manage to graduate by the thesis development modality; in the different faculties of public universities, the number of graduates for this modality is low. This research analyses the particular situation of graduates in the faculty of Systems Engineering and Computer Science of the Universidad Nacional Mayor de San Marcos from 2014, where less than $10 \%$ of the total graduates were identified, graduate by the modality of thesis support and that more than $90 \%$ graduate through various modalities that do not include making a thesis; the consequence of this is the small amount of thesis generated and therefore the low research index as well as the null publication of scientific articles by our graduates. Therefore, this research aims to increase the percentage of graduates by the thesis development modality through collaborative motivation using virtual platforms and support graduates in the publication of scientific articles. At the end of the research, more than $50 \%$ of graduates by the thesis development modality were increased; the publication of scientific articles generated by graduates through the thesis development modality based on the results of their research was also increased
\end{abstract}

Keywords: Graduates, thesis, collaborative motivation, collaborative competence, virtual platforms, scientific publication. University

\section{Introduction}

According to Table 1, in the Faculty of Systems Engineering, the percentage of graduates by the thesis development modality concerning the total number of graduates, in 2014, the year in which this research begins, was less than $10 \%$, while just over $90 \%$ graduated by other modalities. On the other hand, students their university studies with advanced thesis work, since in the last three cycles, they take courses in which they develop their research work and advance with the development of their thesis. We consulted many graduates on the reason why, instead of preferring to graduate because of the thesis development modality, they opted for another modality, and all agreed that the reason was the great difficulties they encountered in the cumbersome process in that modality and that, on the contrary, by the other modalities everything was more manageable.

Therefore, we consider our main problem is the low percentage of graduates by the thesis development modality. The linked question would be: To what extent does collaborative motivation using virtual platforms contribute to the increase in graduates' percentage by the thesis development modality?

At the end of 2014, we also identified that graduates by the thesis development modality do not publish or generate scientific articles binding on the research developed in their thesis. Hence, it is considered that the second problem is the lack of advice and motivation to graduates in the generation and publication of articles generated from their research project. The linked question would be: To what extent does collaborative motivation using virtual platforms contribute to thesis graduates publishing scientific articles?

Consequently, our main objective is to increase graduates' percentage by the thesis development modality through collaborative motivation using virtual platforms. Our secondary objective is to support graduates by the thesis development modality to publish scientific articles binding to the research developed in their thesis.

Table 1 shows the number of graduates per year from 2014 to 2019, distributed in the thesis development modality and other modalities. 
Table 1. Graduates of the Faculty of Systems Engineering from 2014 to 2019.

\begin{tabular}{lllllll}
\hline Graduation mode & $\mathbf{2 0 1 4}$ & $\mathbf{2 0 1 5}$ & $\mathbf{2 0 1 6}$ & $\mathbf{2 0 1 7}$ & $\mathbf{2 0 1 8}$ & $\mathbf{2 0 1 9}$ \\
\hline Thesis development & 10 & 26 & 17 & 33 & 16 & 13 \\
\hline other modalities & 97 & 53 & 29 & 36 & 40 & 12 \\
\hline Total graduates & 107 & 79 & 46 & 69 & 56 & 25 \\
\hline
\end{tabular}

Source: (Anicama et al., 2015), (Lama et al., 2016), (Summer et al., 2017-2020)

\section{Conceptual Framework}

\subsection{Virtual educational platforms}

They are systems that manage online learning environments and offer extensive communication and collaboration possibilities between various learning processes (Pineda and Castañeda, 2013). The contents to be shared are texts, images, sounds, videos, among others, and the objective is the transfer of knowledge-seeking that there is a collaborative environment among the participants.

\subsection{Virtual educational platforms and collaborative competition}

The different virtual platforms are importantly supported in the development of collaborative competencies, and in the current conditions of interconnection and multidisciplinary, it is a great alternative to support collaborative research (Paredes et al., 2017). "This idea is shared and addressed by UNESCO at the Regional Conference on Higher Education, held in Córdova, Argentina, in June 2018" (Román et al., 2018). Today, we live in a competitive world more than ever, where everyone wants to be better, but a good alternative to achieve this is by properly seeking a strategic partner (Vega, 2020). Virtual environments allow us to build teams so that their members can easily share their strengths. There are three types of relationships in the learning processes: Individualist, Competitive and Collaborative; collaborative learning stands out for its results as it allows members to achieve their learning teaching goals, if and only by helping their peers achieve their own (Ferreiro and Espino, 2013). The most rescued collaborative teamwork is that you learn more when you collaborate in your partner's learning. The tools that promote collaborative learning and teamwork in virtual environments can be grouped into: communicative, among which are emails, blogs, Twitter, skype, youtube; Chat, forums, Facebook, google docs; and construction Wikis, prezis; to these, we must add the recent platforms of the market such as zoom, google meet, classroom among others, "in this environment spaces are promoted for reflection, which can be entered at any time, that adapt to the rhythm of individual learning and whose work dynamics are completely opposed to the classic transmission of knowledge". (Ruíz et al., 2015)

\subsection{Virtual educational platforms to support research tutoring for college students}

"The training of young researchers is an outstanding topic in the Institutions of Higher Education globally and, therefore, in Latin America, from Mexico to Patagonia through Venezuela, Colombia, and Brazil. In this topic, there are countless researchers, from Tobias and Lopatto to researchers today, who support and argue the need for university research, that is, that students guided with the tutoring of their teachers do research and such research is of quality". (Lagunes, 2015)

\subsection{Online resources for collaborative learning}

ICTs play a very important role in collaborative learning because they enable online interaction between teachers and students, access to information and content, and tracking student progress; among the usefulness of ICT for collaborative learning we have: synchronous communication, asynchronous communication, data transfer, shared applications, meeting call and shared navigation; Among some applications in online teaching, it is mentioned that the use of blogs is a good alternative, defining the blog as a website where users deposit content of type text, documents, images videos, etc. On some topics, visitors can comment or flirt to another blog; some use blogs to organize their ideas, while others write for large audiences on the Internet. They are a collective means of communication that promotes the creation and consumption of original information that provokes great efficiency, personal reflection, and debate. (Ruíz et al., 2015). ICTs also provide more formal and reliable systems for exchanging information, such as digital signatures. (Córdova et al., 2020) 


\subsection{Role of the research teacher since his social practice (Flores et al., 2020)}

The incentive to research for the thesis generation depends on the advisors as they must be in continuous and open cooperation with students. Advisers should form a network integrating teachers from different countries and disciplines, which supports a broader view of research in Ibero-America.

Figure 1 presents research activities and tasks that a research teacher must have as a tutor-adviser to research projects.

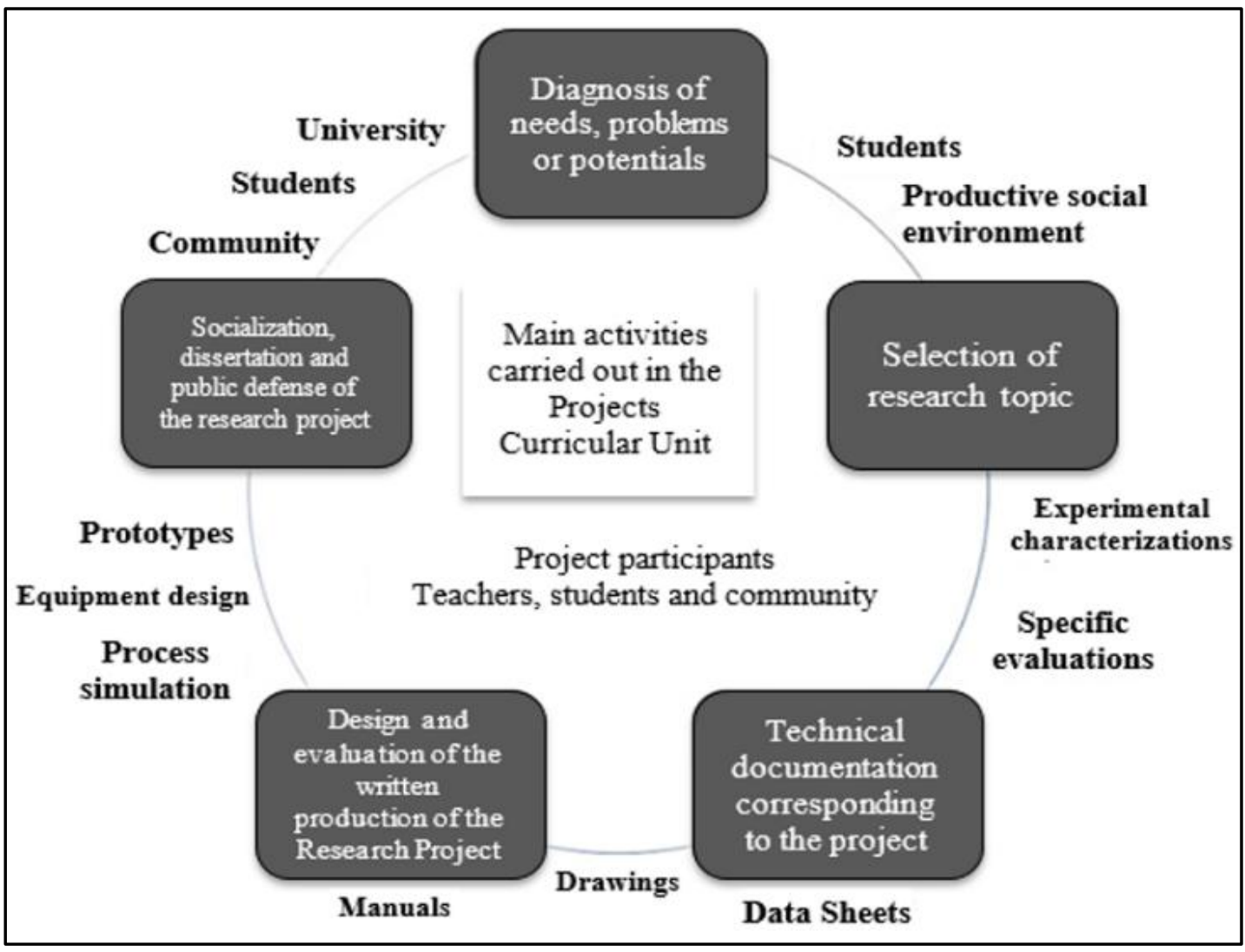

Figure 1. Research activities and tasks of a research teachertutor-adviser (Flores et al., 2020)

\subsection{The role of the advisor in the collaborative learning process}

(Ruiz and Aguilar, 2017), In the collaborative learning model, the advisor must not only transmit knowledge, but he must also generate in his students the capacity for creativity and research, for this, it is necessary to work in a collaborative model in virtual environments; he must analyze the personality of each student and condition himself as far as possible to his habits and customs of study and work, permanently maintaining a very dynamic communication. In constructivist learning, the advisor is characterized by being the great motivator of student learning; in coordination with his students, he sets specific objectives, induces his students to share their knowledge with their peers through learning strategies that contribute attributes to the attitudinal formation, encourages and stimulates students to give their opinions, propose, analyze, and criticize a subject with evidence, to be creative and participate in an open and meaningful dialogue.

According to (Ruiz and Aguilar, 2017), the most important requirements that a virtual advisor must have are:

- Enabling the use of information and knowledge bases

- Empowering the self-directed learning process

- Manage the learning environment, guide students in developing collaborative experiences, monitor student progress, provide feedback that supports the education work, and spread achievements.

- Having fluid access to the student's work and promptly making observations and suggestions for improvement

Figure 2 shows the competencies that a teaching research project advisory should have. 


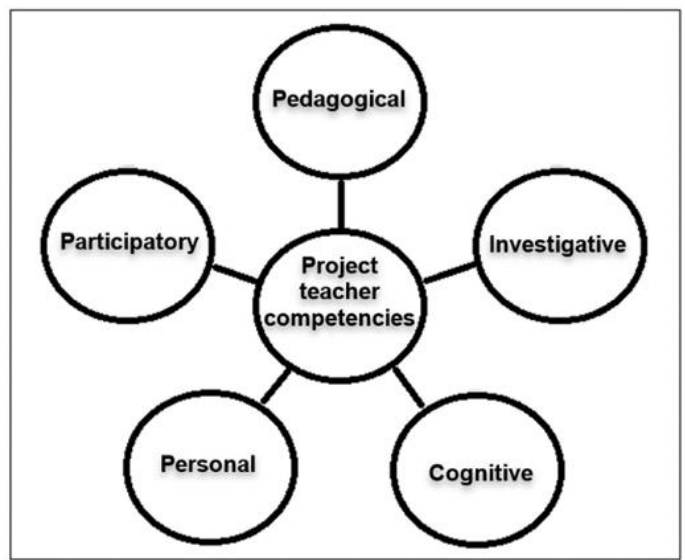

Figure 2. Competencies of the research teacher (Flores et al. 2020)

\section{Methodological framework}

\subsection{Population}

The experiments will be annual. Therefore, each experiment's population will be the set of students who have completed their studies and have not yet graduated. Table 2 shows the number of students with completed studies and graduates in the different modalities from 2014 to 2019; we can see that the population size for 2014 is 20 and for 2015 is 100 .

Table 2. Students with completed studies and graduates from 2014 to 2019.

\begin{tabular}{lllllll}
\hline Students with completed studies/Graduates & $\mathbf{2 0 1 4}$ & $\mathbf{2 0 1 5}$ & $\mathbf{2 0 1 6}$ & $\mathbf{2 0 1 7}$ & $\mathbf{2 0 1 8}$ & $\mathbf{2 0 1 9}$ \\
\hline With completed studies & 127 & 179 & 160 & 203 & 158 & 165 \\
\hline Graduates & 107 & 79 & 46 & 69 & 56 & 25 \\
\hline Thesis development & 10 & 26 & 17 & 33 & 16 & 13 \\
\hline Other modalities & 97 & 53 & 29 & 36 & 40 & 12
\end{tabular}

Source: (Anicama et al., 2015), (Lama et al., 2016), (Summer et al., 2017-2020)

\subsection{Sample}

Whereas the experiments will be annual, each experiment's sample will be students with completes studies voluntarily enrolled in each experiment; each sample is described in detail when you present each experiment.

\subsection{Methodology}

The application of collaborative motivation will be carried out sequentially the following activities:

$\bullet$

$\bullet$

$\bullet$

-

-

-

$\bullet$

$\bullet$
Activity 1. Motivating advertising for stakeholders to sign up

Activity 2. Data collection and selection of stakeholders

Activity 3. Execution of advice to participants

Activity 4. Constant motivation

Activity 5. Monitoring the process

Activity 6. Support in Thesis development

Activity 7. Writing and publishing scientific articles

Activity 8. A recognition ceremony for graduates and advisors

\subsection{First Experiment: Support program to graduation by thesis development - 2014}

\section{The population of the first experiment:}

As explained in numeral 3.1 and the population size for the year 2014 was 20.

\section{Sample of the first experiment:}

According to Table 5, there are 18 registered. 


\section{Activity 1. Motivating advertising for stakeholders to sign up}

Before the publicity aimed at graduates, teachers who wish to participate as thesis advisers were called; this time, six teachers expressed their willingness to support.

Table 3 shows the list of teachers who expressed their willingness to support those registered as thesis advisers.

Table 3. Teachers who agreed to participate as thesis advisers.

\begin{tabular}{l}
\hline Thesis adviser teachers \\
\hline Cesar Angulo \\
\hline Percy de la Cruz \\
\hline Hugo Vega \\
\hline Santiago Moquillaza \\
\hline José Piedra \\
\hline Jorge Chávez \\
\hline
\end{tabular}

The advertising was made by sending emails to the graduates of our population, in that message was provided with the requirements, the list of teaching advisors so that they can choose them according to their thesis topic, the corresponding schedule, and all the details required to participate in the project, they only had to answer the mail attaching their requirements. An interesting alternative that could be considered for future work is proximity marketing through mobile applications (Martínez et al., 2020). Table 4 shows the requirements provided to stakeholders so that they can enroll in this project.

Table 4. Requirements to enroll in the support program to graduation by thesis

\begin{tabular}{l}
\hline Requirements \\
\hline Have completed their studies \\
\hline Having an advanced thesis project \\
\hline Have availability to work intensively \\
\hline No payment is required for support \\
\hline
\end{tabular}

\section{Activity 2. Data collection and selection of stakeholders}

After sending more than a dozen emails and attending many queries by mail and phone, we finally have 18 enrollees who chose their respective advisor teachers according to their thesis topic's affinity. On 6 July 2014, the registration period for participation in this project was completed. Table 5 shows the list of the registered and teachers selected as thesis advisors.

Table 5. List of participants enrolled in the project.

\begin{tabular}{lll}
\hline & Participants enrolled & Advisor Teacher \\
\hline 1 & Chuquizuta Rojas Caroll & Cesar Angulo \\
\hline 2 & Prudencio Ramirez Raimundo & Cesar Angulo \\
\hline 3 & Barrios Lambruschini Daniel & Cesar Angulo \\
\hline 5 & Espinoza Monteagudo Robert & Cesar Angulo \\
\hline 6 & Vilca Ypanaqué Jorge & Cesar Angulo \\
\hline 7 & Landeo Jacinto Juan & Hugo Vega \\
\hline 8 & Tortella Melchor John & Hugo Vega \\
\hline 9 & Alcantara Quispe Alex & Hugo Vega \\
\hline 10 & Arauco Villar José & Jorge Chavez \\
\hline 11 & Casasola Huamancusi Cesar & Jorge Chavez \\
\hline 12 & Yucra Puma Magaly & Jorge Chavez Chavez \\
\hline 13 & Bonifacio Chanca Edwin & José Piedra \\
\hline 14 & Camacho Aybar Jonathan & José Piedra \\
\hline 15 & Huapaya Vasquez José & Percy de la Cruz \\
\hline 16 & Torres Llatas Gavy & Percy de la Cruz \\
\hline 17 & Grados Guerra Luis & Santiago Moquillaza \\
\hline 18 & Vega Ucharima Manuel & Santiago Moquillaza \\
\hline
\end{tabular}




\section{Activity 3. Execution of advice}

Thesis advisor teachers provided personalized and constant support to their advisors to develop their thesis projects.

\section{Activity 4. Constant motivation}

The consultancies' attention was always promptly implemented, and precise suggestions for the corresponding improvements this motivated participants significantly and supported by providing them with information on formal procedures for registering their thesis projects in the school. Likewise, as part of the constant motivation of this process, for collaborative support among the whole team, a virtual platform was implemented in which participants shared their progress with their colleagues and advisors so that everyone can appreciate their progress so that they could have clear examples to rely on the development of their projects.

\section{Activity 5. Monitoring the process}

The monitoring of the process was carried out very quickly, thanks to the virtual platform implemented. It also served to constantly visualize the progress of developing the thesis's thesis and the contributions and observations generated by the teaching advisors. Figure 3 shows the Blog implemented to support process monitoring

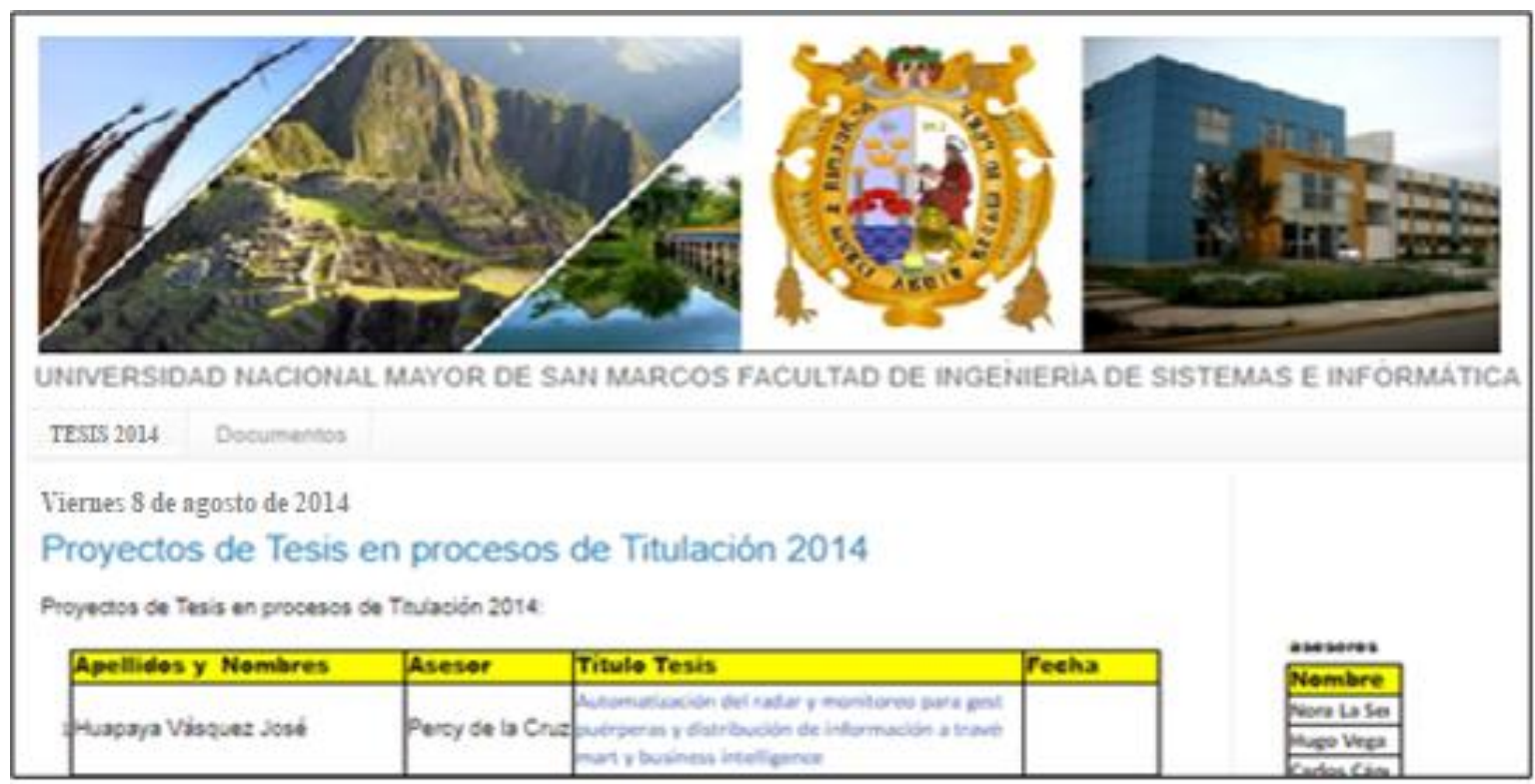

Figure 3. Project progress monitoring blog. Source: Authors

The blog can be viewed at http://titulacionportesisunmsmfisi.blogspot.com/search/label/Tesis\%202014

\section{Activity 6. Support in Thesis development}

When a thesis has the approval of his advisor and his reviewers, the school director sets a date for public defense of the thesis; for this, the participants are given a motivating talk and recommendations on the details so that they have an adequate presentation and attend with total confidence the formal act. After six months of intense work, the Theses' defenses began on December 17, 2014, and ended on January 30, 2015. Figure 4 shows an act of oath after culminating in defense of the thesis.

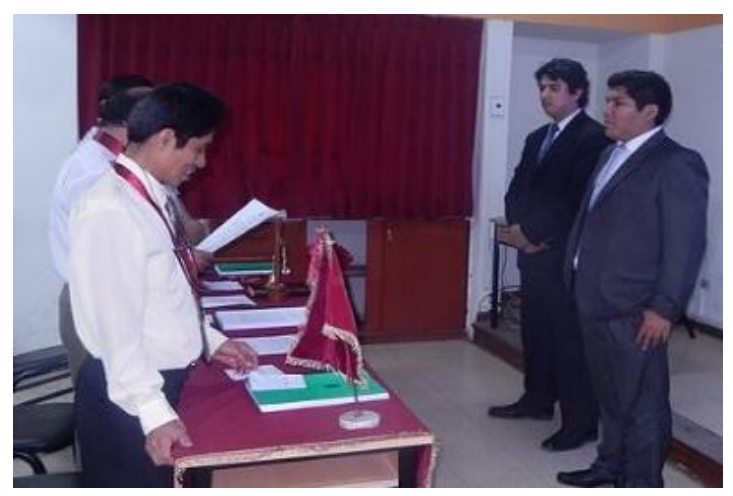


Figure 4. Act of oath after culminating in defense of the thesis

Table 6 shows the list of participants who successfully defended their thesis

Table 6. Participants who successfully defended their thesis

\begin{tabular}{|c|c|c|c|}
\hline & Graduated & Advisor & $\begin{array}{l}\text { Date } \\
\text { Defending }\end{array}$ \\
\hline 1 & Landeo Jacinto Juan & Hugo Vega & $17 / 12 / 2014$ \\
\hline 2 & Vega Ucharima Manuel & $\begin{array}{l}\text { Santiago } \\
\text { Moquillaza }\end{array}$ & $14 / 01 / 2015$ \\
\hline 3 & Grados Guerra Luis & $\begin{array}{l}\text { Santiago } \\
\text { Moquillaza }\end{array}$ & $15 / 01 / 2015$ \\
\hline 4 & $\begin{array}{l}\text { Prudencio } \\
\text { Raimundo }\end{array}$ & Cesar Angulo & $15 / 01 / 2015$ \\
\hline 5 & Torres Llatas Gavy & Percy de la Cruz & $15 / 01 / 2015$ \\
\hline 6 & Barrios Lambruschini Daniel & César Angulo & $16 / 01 / 2015$ \\
\hline 7 & $\begin{array}{ll}\text { Espinoza } & \text { Monteagudo } \\
\text { Robert } & \end{array}$ & César Angulo & $16 / 01 / 2015$ \\
\hline 8 & Chuquizuta Rojas Caroll & Cesar Angulo & $22 / 01 / 2015$ \\
\hline 9 & Portella Melchor John & Hugo Vega & $22 / 01 / 2015$ \\
\hline 10 & Tomasto Farfán Carool & Hugo Vega & $22 / 01 / 2015$ \\
\hline 11 & Arauco Villar José & Jorge Chavez & $23 / 01 / 2015$ \\
\hline 12 & Vilca Ypanaqué Jorge & César Angulo & $23 / 01 / 2015$ \\
\hline
\end{tabular}

\section{Activity 7. Writing and publishing articles}

With his advisor's support, the graduates proceed with the scientific article's writing and submit it to some magazine or congress for publication. Table 7 shows the list of graduates who published their articles. (Petrlik et al., 2019), (Motta et al., 2019)

Table 7. Graduates who published their scientific articles

\begin{tabular}{llll}
\hline & Graduated & Advisor & $\begin{array}{l}\text { Published } \\
\text { article }\end{array}$ \\
\hline 1 & Barrios Lambruschini Daniel & César Angulo & Yes \\
\hline 2 & $\begin{array}{l}\text { Espinoza } \\
\text { Robert }\end{array}$ & Monteagudo & César Angulo \\
\hline 3 & Landeo Jacinto Juan & Hugo Vega & Yes \\
\hline 4 & Portella Melchor John & Hugo Vega & Yes \\
\hline 5 & Tomasto Farfán Carool & Hugo Vega & Yes \\
\hline 6 & Torres Llatas Gavy & Percy de la Cruz & Yes \\
\hline 7 & Grados Guerra Luis & $\begin{array}{l}\text { Santiago } \\
\text { Moquillaza }\end{array}$ & Yes \\
\hline
\end{tabular}

Activity 8. A recognition ceremony for graduate students for thesis development and advisor teachers

In coordination with the authorities on budgetary issues, it was agreed to hold this ceremony at the end of the experiment to support graduation by the thesis development modality - 2015 , to have many graduates who receive their recognition.

\subsection{Second Experiment: Support program to graduation by thesis development- 2015}

The population of the second experiment:

As explained in numeral 3.1, the population size for 2015 is 100.

Sample of the second experiment:

This time, according to Table 8, we have 5 registered.

Activity 1 to Activity 7

For this experiment, like our first experiment, activities were performed sequentially from 1 to 7 , but this time, only 5 participants were recorded; although the number of participants was lower, everyone managed to develop their thesis. Table 8 shows the list of those who managed to develop their thesis. 
Table 8. Graduates who successfully defended their thesis

\begin{tabular}{llcl}
\hline & Graduates & Advisor Teacher \\
\hline 1 & $\begin{array}{l}\text { Maguiña } \\
\text { Lucero }\end{array}$ & Agurto & \\
\hline 2 & $\begin{array}{l}\text { Riveros } \\
\text { Cecilia }\end{array}$ & Cáceres & $\begin{array}{l}\text { Santiago Maria Huayna } \\
\text { Moquillaza }\end{array}$ \\
\hline \multirow{2}{*}{3} & $\begin{array}{l}\text { Zevallos } \\
\text { Marino }\end{array}$ & Yapias & $\begin{array}{l}\text { Santiago } \\
\text { Moquillaza }\end{array}$ \\
\hline 4 & Córdova Quispe Marilú & Hugo Vega \\
\hline 5 & Diaz Ramos Enrique & Hugo Vega \\
\hline
\end{tabular}

\section{Activity 8. A recognition ceremony for graduate students for thesis development and advisor teachers}

Continuing with the support process to graduation by the thesis development through collaborative motivation, the ceremony was held to recognize the important work done by our graduates, who achieved the successful defense of their thesis; in addition, graduates who had managed to publish their scientific articles linked to their thesis in journals or congresses were awarded the honor of merit. The faculty authorities carried out this ceremony, which the graduates attended, advisor teachers, and our graduates' parents and relatives' significant presence.

Figure 5 shows the Dean of the faculty presiding over the ceremony of recognition of graduates for the thesis development modality, accompanied by the Vice-Dean of Research and the Academic Vice-Dean.

Figure 6 shows graduates and advisor teachers receiving their diploma of recognition.

Figure 7 shows parents' important presence as a motivating factor and the faculty's dean giving his closing speech.

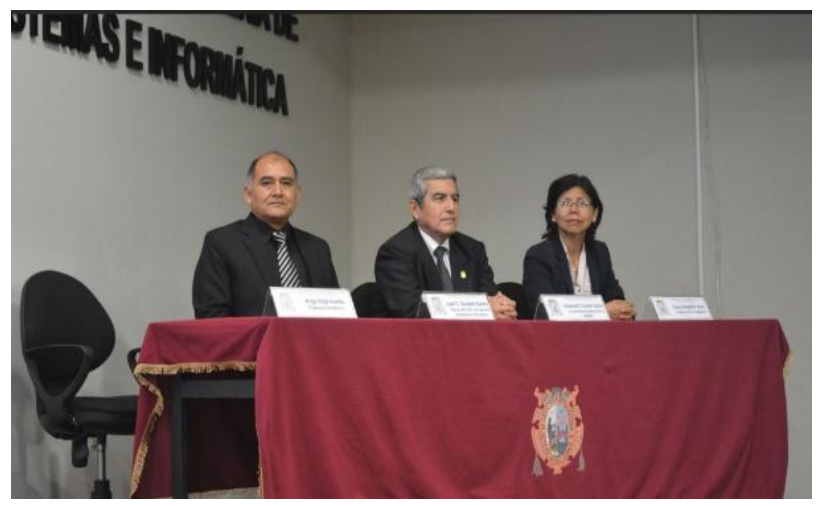

Figure 5. Authorities of the faculty in charge of the ceremony of recognition of graduates by thesis
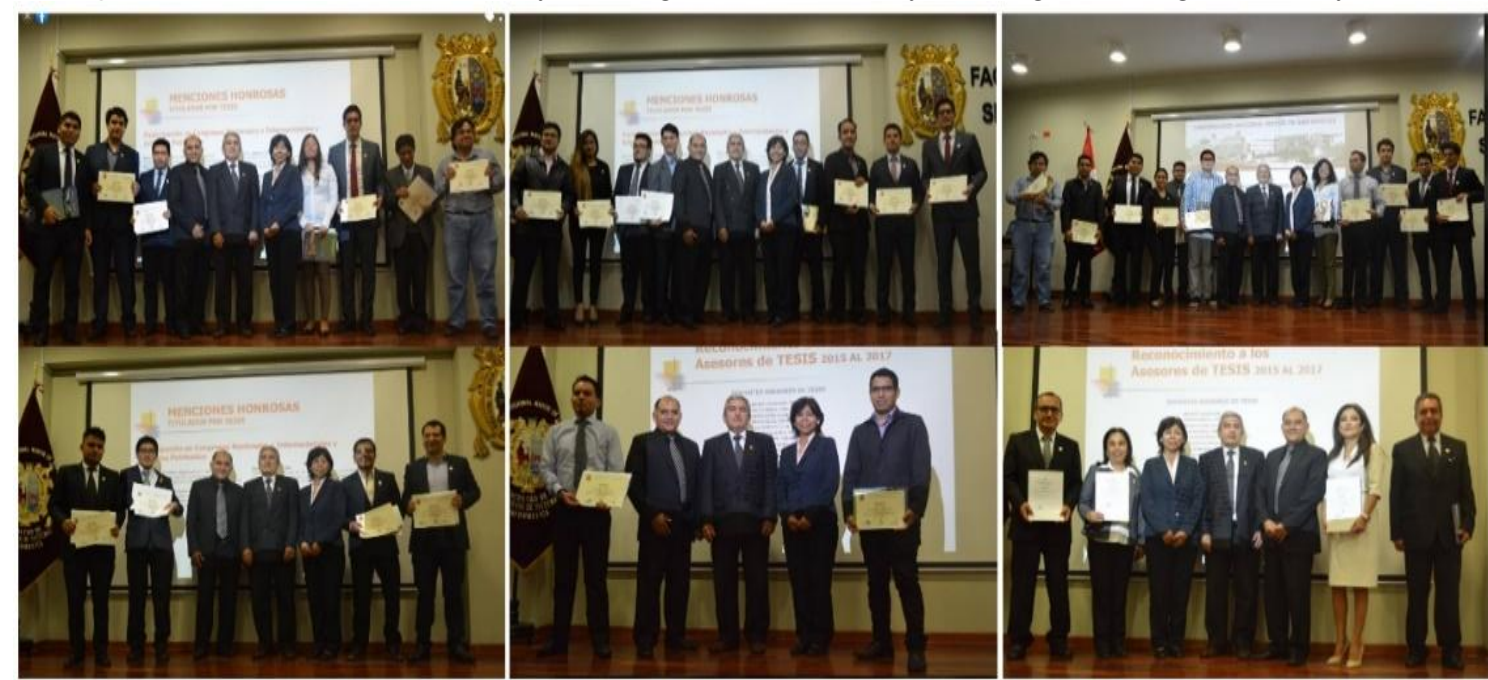

Figure 6. Graduates by thesis and advisors receiving their diploma of recognition. 


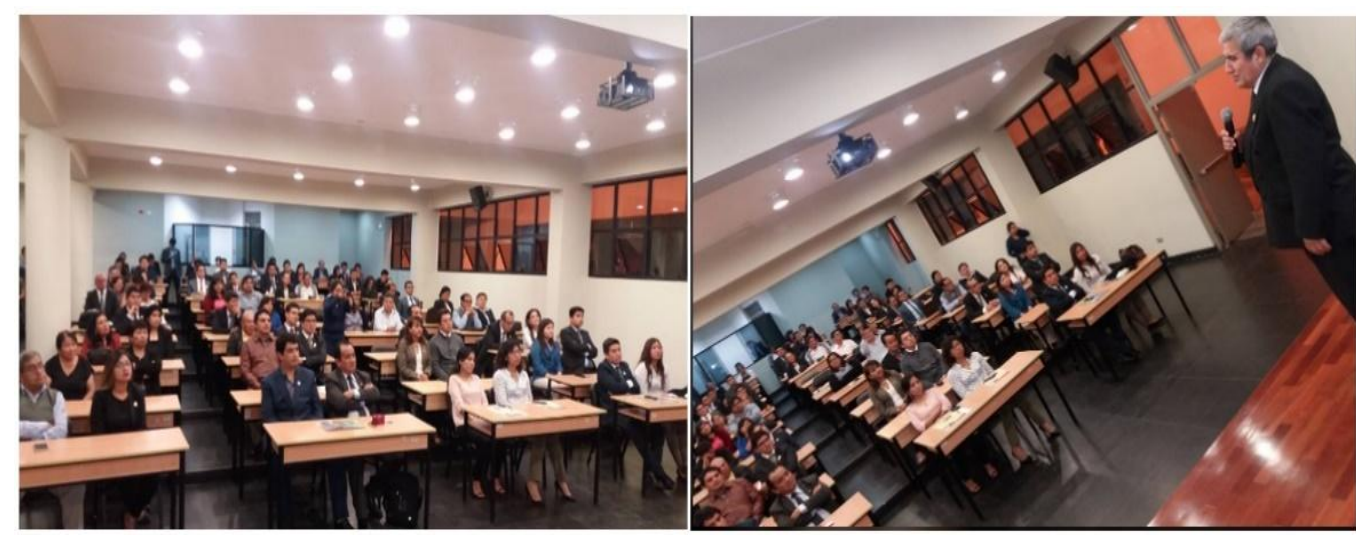

Figure 7. Dean of the faculty delivering his closing speech

\section{Results}

In summary form, we present the results achieved in the two experiments:

Table 9 shows the number of students registered and those who managed to complete their thesis development. It can be seen that of the 23 students who participated in both experiments, 17 managed to graduate; that is, $74 \%$ of the participants managed to culminate with the development and defense of their thesis.

Table 9. Students registered in the project and number of graduates.

\begin{tabular}{llll}
\hline Enrollees and Graduates & $\mathbf{2 0 1 4}$ & $\mathbf{2 0 1 5}$ & Total \\
\hline Enrollees & 18 & 5 & 23 \\
\hline Graduates by thesis development & 12 & 5 & 17 \\
\hline Effectiveness & $67 \%$ & $100 \%$ & $74 \%$
\end{tabular}

Source: Authors

Table 10 shows the increase in the percentage of graduates by the thesis development modality; in 2015 was $85 \%$, in 2016 was $42 \%$, and during the two years of the investigation, it was $71 \%$. The results shown in Table 9 are reflected in the following year of Table 10.

Table 10. The number of graduates by the thesis development from 2014 to 2016.

\begin{tabular}{llll}
\hline Graduates by Thesis development & $\mathbf{2 0 1 5}$ & $\mathbf{2 0 1 6}$ & Total \\
\hline Normal process & 14 & 12 & 24 \\
\hline Project - support for thesis graduation & 12 & 5 & 17 \\
\hline Increase & $85 \%$ & $42 \%$ & $71 \%$ \\
\hline
\end{tabular}

Source: (Lama et al., 2016), (Summer et al., 2017)

The participants who managed to conclude their thesis, supported by his advisers, generated an article linked to his research; Table 11 shows 17 articles generated, 7 of which were published, representing $41 \%$ effectiveness.

Table 11. Number of articles published by thesis graduates

\begin{tabular}{llll}
\hline Published articles & $\mathbf{2 0 1 5}$ & $\mathbf{2 0 1 6}$ & Total \\
\hline Graduates by thesis development & 12 & 5 & 17 \\
\hline Published articles & 7 & 0 & 7 \\
\hline Effectiveness & $85 \%$ & $42 \%$ & $41 \%$ \\
\hline
\end{tabular}

\section{Conclusions}

Collaborative motivation using virtual platforms contributes significantly to the increment of graduates' percentage by the thesis development modality; according to the results of this research, shown in Table 10, this contribution was $71 \%$.

Collaborative motivation using virtual platforms contributes significantly to graduate graduates' thesis development modality to publish scientific articles binding on their research outcome. According to Table 11, $41 \%$ of graduates by thesis development were able to publish their scientific articles linked to their research 


\section{References}

Anicama, J., Soldán, S., Quispe, C., Malca, F. (2015). Statistical compendium 2015. The National University of San Marcos. General Planning Office

Córdova, J., Vega, H., Rodriguez, C., and Escobedo, F. (2020). Digital signature based on asymmetric cryptography for clinical history generation. 3C Technology. Innovation glosses applied to SMEs, 9(4), 6585. https://doi.org/10.17993/3ctecno/2020.v9n4e36.65-85

Ferreiro, G. y Espino, M. (2013) The ABC of cooperative learning: Teamwork to learn and teach. Mexico, Trillas.

Flores, E., Loaiza, A., \& Rojas de Ricardo, G. (2020). Role of the research teacher from his social practice. Journal Scientific, 5(15), 106-128, e-ISSN: 2542-2987. Retrieved from: https://doi.org/10.29394/Scientific.issn.2542-2987.2020.5.15.5.106-128

Holgado, C. (2016). New university times and TICs. Dialnet. Editorial Area of Innovation and Development, S.L ISBN: 978-84-945424-0-4

Lagunes, A. (2015), Virtual Educational Platforms to support research mentoring for university students. Conference: XXI International Congress on Bimodal Education At: Medellin, Colombia, Volume: 1.

Lama, M., Soldán, S., Quispe, C., Malca, F. (2016). Statistical compendium 2016. National University of San Marcos. General Planning Office

Martínez, G., Vega, H., Rodriguez, C., and Guzmán, Y. (2020). Proximity marketing via mobile app with Beacon devices. 3C ICT. ICT Development Notebooks, 9(4), 89-111. https://doi.org/10.17993/3ctic.2020.94.89-111

Motta, V., Guillen, R., Rodriguez, C., (2019). Artificial Neural Networks to optimize learning and teaching in engineering careers. Proceedings of the 2019 International Symposium on Engineering Accreditation and Education, ICACIT 2019, 2019, 9130296. EID: 2-s2.0-85084220713

Román, E., Porras, M., Madrigal, A. and Medina, P. (2018). Latin American educational scenarios. A look from college. Sancti Spíritus, Cuba. ISBN: 978-612-46680-6-7

Ruíz, E., Martínez, N. y Galindo, R. (2015). Collaborative learning in virtual environments. Cenid Publishing House. Mexico. ISBN: 978-607-8435-10-4

Paredes, J., Calvopiña, D., Velasco, V. and Alvarez, J. (2017). Knowledge management and its relevance in University Education. Hermes Scientific Journal, 19, 475-493. http://dx.doi.org/10.21710/ rch.v19i0.374

Petrlik, I., Rodriguez, C., Gonzales, P.,(2019) M-Learning applied to the improvement of the learning of university engineering students. Proceedings of the 2019 International Symposium on Engineering Accreditation and Education, ICACIT 2019, 2019, 9130215. doi: 10.1109/ICACIT46824.2019.9130215

Pineda, P. and Castañeda, A. (2013). LMS as a collaborative tool in education. A comparative analysis of the world's largest platforms. V Latin International Congress of Social Communication

Ruíz, M. and Aguilar, R. (2017). University professor's competencies. Preparation and validation of a selfassessment questionnaire. Mexico. Ibero-American Journal of Higher Education (RIES), VIII(21), 37-65

Summer, L., Soldán, S., Quispe, C., Malca, F. (2017), (2018), (2019), (2020). Statistical compendium 2017. National University of San Marcos. General Planning Office 